\title{
A morte estampada nas capas de jornais: uma análise semiótica do "Massacre de Realengo"
}

\author{
The death printed in newspapers front pages: \\ a semiotic analysis of "Realengo's Massacre"
}

Raiane Nogueira Gama

Universidade Federal Fluminense, Rio de Janeiro, Rio de Janeiro / Brasil raianenog@gmail.com

Renata Mancini

Universidade Federal Fluminense, Rio de Janeiro, Rio de Janeiro / Brasil renata.mancini@gmail.com

Resumo: A cobertura jornalística de fatos de forte apelo emocional, como mortes trágicas e/ou violentas, suscita uma importante reflexão acerca dos limites entre o que se considera um modo de noticiar moderado ou sensacionalista. O estabelecimento de categorizações duras entre os dois perfis editoriais pode ser frágil. A fim de verificar essa hipótese, este trabalho analisa como doze jornais impressos brasileiros repercutiram o caso conhecido como "Massacre de Realengo" nas capas do dia seguinte ao fato. No episódio, doze estudantes de uma escola municipal da cidade do Rio de Janeiro foram assassinados por um ex-aluno, que se matou em seguida. A análise semiótica permitiu a identificação de marcas textuais e apelos estéticos característicos do jornalismo dito sensacionalista em todos os veículos examinados. Além disso, possibilitou observar a proximidade de $O$ Globo ao polo mais apelativo de um continuum traçado com as capas, em uma gradação qualitativa de efeitos de sentido. O posicionamento do veículo, reconhecido no mercado por adotar um perfil de maior sobriedade, configurou uma quebra de expectativa. Os resultados mostraram que as fronteiras nítidas entre os 
estilos enunciativos moderado e sensacionalista se desfazem na dimensão pragmática e complexa da práxis jornalística.

Palavras-chave: Massacre de Realengo; semiótica francesa; jornalismo; sensacionalismo.

Abstract: The press coverage of facts with strong emotional appeal, such as tragic and/or violent deaths, raises an important discussion about the limits between what is considered a moderated or a sensationalist mode of reporting. The establishment of clear-cut boundaries between both editorial profiles can be fragile. In order to verify this hypothesis, this article analyses twelve different approaches of Brazilian newspaper front pages depicting the case known as the "Realengo's Massacre" in the next day of the fact. In the episode, twelve schoolchildren of a municipal school in the city of Rio de Janeiro were murdered by an ex-student who ended up shooting himself. The semiotic analysis here presented allowed the identification of text marks and aesthetic appeals of the journalism called sensationalist in all examined newspaper covers. It was surprising to observe the proximity of $O$ Globo - a mainstream well established newspaper in Brazil - to the most appellative pole of the continuum traced with all front pages, in a qualitative gradation of meaning effects. This position set up an expectation break, since the newspaper is recognized by its somehow moderate profile. The results showed that the clear-cut boundaries between moderated and sensationalist enunciation styles fall apart in the pragmatic and complex dimension of the journalistic praxis. Keywords: Realengo's Massacre; discursive semiotics; journalism; sensationalism.

Recebido em: 31 de maio de 2016. Aprovado em: 26 de setembro de 2016.

\section{0 "Massacre de Realengo"}

A cobertura jornalística de mortes trágicas e/ou violentas motiva um debate corrente nos campos da Comunicação Social e dos estudos linguísticos quanto à construção discursiva desse tipo de notícia. Uma questão fundamental é levantada: é possível noticiar um fato apelativo em sua essência, por exemplo, o assassinato de doze alunos em uma 
escola, sem explorar componentes emocionais, como a brutalidade da ação e o sofrimento de parentes e amigos das vítimas? Ancorado na metodologia proposta pela semiótica francesa, este artigo busca verificar a hipótese de que, nesses casos, tanto os jornais considerados moderados quanto os chamados "espreme que sai sangue" (cf. ANGRIMANI, 1995) tendem a se render a marcas textuais e a apelos estéticos característicos do jornalismo dito sensacionalista. Para tanto, serão examinadas as capas de doze jornais impressos brasileiros publicadas no dia seguinte ao "Massacre de Realengo". A análise se organizará em um continuum, das páginas menos às mais apelativas. Será dado, ainda, um tratamento especial a $O$ Globo, uma vez que o posicionamento do jornal impulsiona uma reflexão mais aprofundada acerca da fragilidade da fixação de fronteiras nítidas entre diferentes perfis editorais. $\mathrm{O}$ veículo também ganha destaque por sua relevância: é o segundo maior impresso do Brasil de circulação paga, por ano, e o primeiro do Rio de Janeiro (ANJ, 2015), ${ }^{1}$ onde ocorreu o episódio descrito a seguir.

Na manhã do dia 7 de abril de 2011, um ato de violência sem precedentes no Brasil mobilizou a população e a mídia. O caso ficou conhecido como "Massacre de Realengo". Na ocasião, Wellington Menezes de Oliveira, de 23 anos, assassinou doze adolescentes na Escola Municipal Tasso da Silveira, no bairro de Realengo, na Zona Oeste do Rio de Janeiro. Ex-aluno, ele entrou no colégio alegando que daria uma palestra, como parte das celebrações de 40 anos da instituição. Mas sua verdadeira intenção era promover um ataque.

Com dois revólveres e muita munição, conforme relatado pela imprensa, o jovem atirou contra mais de vinte alunos no segundo andar da escola. Dez meninas e dois meninos morreram e outros doze estudantes ficaram feridos. As vítimas tinham entre 12 e 15 anos. Ao subir até o terceiro andar para dar sequência à ação, o ex-aluno foi impedido pelo sargento da Polícia Militar Márcio Alexandre Alves, que o atingiu com um tiro na barriga. $\mathrm{O}$ PM fazia uma blitz próxima à escola, quando foi chamado por um dos feridos. Baleado, Wellington caiu na escada e se matou com um tiro na cabeça. Junto ao corpo, foi encontrada uma carta com indicações para o seu sepultamento, revelando o plano do atirador de se suicidar após o crime.

${ }^{1}$ Disponível em: <http://goo.gl/nHMxYm>. Acesso em: 9 mai. 2016. 
Devido ao forte apelo inerente ao fato e por seu ineditismo no Brasil, o "Massacre de Realengo" ganhou grande repercussão na mídia. Instantes após o ocorrido, registros das câmeras de segurança da escola, vídeos amadores de alunos ensanguentados e uma foto de Wellington morto circulavam em sites de notícias e telejornais. No dia seguinte ao ataque, as mesmas imagens estampavam as páginas dos impressos. $\mathrm{O}$ caso foi manchete em mais de oitenta jornais brasileiros e estrangeiros (NET PAPERS, 2011). ${ }^{2}$

Veículos internacionais, como a rede americana $C N N$ e o jornal The New York Times, os britânicos BBC e The Guardian, o espanhol El País, o argentino La Nación, o francês Le Monde e a rede do Qatar al-Jazeera, deram destaque à notícia. Na TV brasileira, jornalistas de telejornais de grande audiência se emocionaram no ar, como a âncora do Jornal Hoje, da TV Globo, Sandra Annenberg, e a repórter do Estúdio I, da Globo News, Anne Lottermann, que chorou ao entrevistar uma sobrevivente. Depoimentos de testemunhas da ação tiveram grande espaço na cobertura, reforçando o efeito de verdade característico da linguagem jornalística.

A postura adotada pelos jornais foi muito questionada, tanto por profissionais da área quanto pelo público, que se manifestou em blogs e redes sociais. Portais especializados divulgaram diversos artigos sobre o assunto. O texto "Tragédia no RJ: cobertura equilibrada ou sensacionalista?", ${ }^{3}$ de Izabela Vasconcelos, publicado no Comuniquese, em 11 de abril de 2011, por exemplo, apresentou visões opostas de dois jornalistas. Enquanto Danilo Angrimani defendeu o posicionamento da imprensa, classificando a cobertura como "ágil e sem exageros" (apud VASCONCELOS, 2011), Laurindo Leal Filho a considerou um "desserviço", um jornalismo sem nenhuma preocupação social, somente mercadológica (apud VASCONCELOS, 2011). Diante da discussão, uma breve teorização faz-se necessária para elucidar como, de fato, se constitui o estilo enunciativo sensacionalista.

\footnotetext{
${ }^{2}$ Disponível em: <http://goo.gl/M3v6GL>. Acesso em: 4 jul. 2011.

${ }^{3}$ Disponível em: <http://goo.gl/XwMnah>. Acesso em: 13 abr. 2011.
} 


\section{0 estilo enunciativo sensacionalista}

O Novo Dicionário da Língua Portuguesa (FERREIRA, 2009, p. 1829) traz as seguintes definições de sensacionalismo: "1. Divulgação e exploração, em tom espalhafatoso, de matéria capaz de emocionar ou escandalizar. 2. Uso de escândalos, atitudes chocantes, hábitos exóticos etc., com o mesmo fim [...]". Pedroso explica como esse tipo de narrativa, de maneira geral, se apresenta para o leitor:

A narrativa [sensacionalista] transporta o leitor; é como se ele estivesse lá, junto ao estuprador, ao assassino, ao macumbeiro, ao sequestrador, sentindo as mesmas emoções. [...] A humanização do relato faz com que o leitor reviva o acontecimento como se fosse ele o próprio autor do que está sendo narrado. (PEDROSO, 1983 apud ANGRIMANI, 1995, p. 17)

Discini (2003, p. 129) define o estilo enunciativo sensacionalista como "uma voz discursiva que grita". Para além da característica inerente ao discurso jornalístico de apresentar um forte efeito de sentido de verdade, nos veículos considerados sensacionalistas, identifica-se o uso exacerbado de estratégias de aproximação, com uma forte iconização, que exacerba a dramaticidade dos fatos noticiados. Barros (2005, p. 69) define iconização como "o investimento figurativo exaustivo final, isto é, a última etapa da figurativização, com o objetivo de produzir ilusão referencial". Nesse caso, o enunciador do jornal utiliza-se ao máximo de figuras - termos mais concretos, que simulam e descrevem o mundo -, a fim de levar o enunciatário ${ }^{4}$ a reconhecer imagens do mundo natural projetadas no texto e, assim, crer na verdade do discurso. Quanto mais figurativizado o texto, maior o efeito de sentido de realidade criado. A iconização vai ao encontro de uma tendência no jornalismo de "visualidade" da informação, expressa não só pelos conteúdos verbais, como também pelos visuais - em que a fotografia ocupa lugar privilegiado (cf. GOMES, 2008).

\footnotetext{
${ }^{4}$ Todo enunciado tem como pressuposto um sujeito da enunciação, que se desdobra em enunciador ("eu", que diz) e enunciatário ("tu", a quem se dirige). Enunciador e enunciatário não são autor e leitor reais, mas perfis depreendidos do texto (cf. FIORIN, 2004).
} 
Outra característica do estilo enunciativo sensacionalista é o não apagamento de marcas da enunciação no enunciado (FIORIN, 2004, p. 22). Ao se projetar, o sujeito da enunciação deixa suas marcas por meio da actorialização, da temporalização e da espacialização. Essas projeções se dão pelos mecanismos das debreagens enunciativa ou enunciva e da embreagem. ${ }^{5}$ A debreagem enunciva actancial é um dos imperativos do discurso jornalístico: o emprego da terceira pessoa constrói simulacros de objetividade e distanciamento. O mesmo se pode observar por meio da embreagem enunciva actancial, quando os veículos midiáticos se chamam pelo nome, usando a terceira pessoa no lugar da primeira - como no teaser "Leia amanhã, no Globo". A debreagem enunciva espacial contribui igualmente para a manutenção desses efeitos. Nos jornais ditos sensacionalistas, porém, são recorrentes formas pessoais de narrar, imprimindo efeitos de subjetividade e aproximação. Gomes (2008, p. 35) afirma que, com isso, julgamentos parciais e envolvimentos passionais se tornam explícitos.

Em relação ao conteúdo verbal, nos jornais considerados sensacionalistas, é recorrente o emprego da linguagem coloquial, oralizada, marcada pelo uso de gírias e, no limite, de expressões vulgares. Quanto à definição dos assuntos e fatos que ganham status de notícia, priorizam-se os fait divers, ${ }^{6}$ os temas da morte e da violência, escândalos e relatos pessoais comoventes, para garantir audiência. Como enfatiza Fiorin, "buscam-se os eventos mais extravagantes e trágicos da vida privada" (2004, p. 21).

O principal traço do estilo sensacionalista é um amplo uso de fotografias, comumente apresentadas como provas irrefutáveis dos fatos. As capas dos jornais considerados apelativos geralmente são estampadas por uma única foto, que ocupa a maior parte da página. Ao retratar a morte, por exemplo, as imagens priorizam seu aspecto mais brutal. É o jornalismo "espreme que sai sangue". Segundo Gomes, nesses veículos,

\footnotetext{
${ }^{5} \mathrm{Na}$ debreagem enunciativa, projeta-se um “eu-aqui-agora”. Na debreagem enunciva, é projetado um "ele-alhures-então". Por fim, na embreagem, ocorre uma suspensão da oposição entre dois termos de cada uma das categorias de pessoa, tempo ou espaço. Neutralizam-se as diferenças entre essas categorias, levando ao uso de uma pessoa com sentido de outra, um tempo por outro ou um espaço por outro (cf. FIORIN, 2005). ${ }^{6}$ Chamam-se fait divers ("fatos diversos") episódios publicados pelos jornais apenas por serem curiosos, inusitados, bizarros, pitorescos (cf. ALENCAR, 2005).
} 
voltados a um público tomado pelo senso comum como "não civilizado" e "inculto":

[...] a dramaticidade causada pelas imagens que mostram a violência e o erotismo, em toda a sua crueza, geralmente expostas nas bancas em locais visíveis ao passante, é o apelo utilizado para reter o olhar desse destinatário e mobilizá-lo para a aquisição e leitura do jornal. (GOMES, 2008, p. 35)

Quanto ao plano de expressão, além de ocuparem um grande espaço, as fotografias usadas pelos jornais tidos como sensacionalistas normalmente apresentam um contraste cromático acentuado. Nas páginas, há poucos elementos verbais. Os títulos das manchetes são escritos em fontes ampliadas, em negrito, mais espessas do que o padrão dos jornais moderados, também ocupando grande espaço. Fiorin destaca que, aqui, ao contrário do que canonicamente se vê na imprensa considerada sóbria, tudo é hiperbólico. Identifica-se um perfil de enunciador mais "rude", que "fala com franqueza":

É um ator redundante, "espaçoso", impaciente, o que se nota na enunciação acelerada. Esse ator tem um corpo avesso à contenção, seus gestos são atabalhoados. Ele não fala, grita. Seu tom de voz nada tem da intensidade das vozes consideradas bem educadas. (FIORIN, 2004, p. 22)

Inversamente, a orientação geral do discurso jornalístico dito moderado é seguir as normas de conduta da atividade. Esse modo de enunciar caracteriza-se principalmente pela construção dos efeitos de sentido de objetividade, neutralidade, imparcialidade, isenção e verdade. De acordo com Fiorin (2004, p. 22), o perfil de enunciador desse tipo de veículo é "sutil, fino, busca compreender o mundo em que vive, apresentase como alguém, aparentemente isento; confiável, porque transmite um saber englobante do mundo". O estilo moderado é marcado, grosso modo, pelo apagamento de marcas da enunciação no enunciado; pelo uso da norma culta e o veto a escolhas vocabulares que denunciem uma visão passional ou subjetiva; pela preferência ao noticiário político, econômico e internacional; e por uma composição visual mais sóbria. 


\section{A morte midiática}

Uma vez definido o estilo sensacionalista, antes da análise do corpus, cabe uma breve contextualização de como esse modo de enunciar se articula na cobertura da morte. Parte do cotidiano, o tema está presente quase diariamente no noticiário, seja dos jornais ditos moderados, seja dos apelativos. Nos considerados sensacionalistas, costuma virar manchete, muitas vezes a única do dia, servindo de estímulo para as vendas. A capa de um jornal funciona como "vitrine", "cartão de visita", que pode definir se uma edição vai ser comprada ou não, pelo seu grau de atratividade. Por isso, a primeira página costuma ser construída com uma forte exploração de recursos de chamamento e apelo. Discini explica que a principal coerção da capa de um jornal é atrair e conquistar o interesse do leitor. A autora a caracteriza como rosto ou espelho, que reflete o direcionamento de cada veículo:

Rosto, já que cada jornal mostra uma feição própria nessa página, como chamariz ao seu leitor, leitor "cevado" mais pelo modo familiar de lhe darem alimento, do que pelo alimento em si. Espelho, já que, nessa primeira página, projeta-se um corpo, o corpo de cada jornal, construído não apenas naquele determinado dia, mas na sequência de dias, semanas, meses e anos, e construído também não apenas por aquilo que diz, mas, principalmente pelo modo como diz. Este corpo, representando uma totalidade, construído por uma recorrência de procedimentos, constitui o estilo de cada jornal. (DISCINI, 2003, p. 118, grifo do autor)

No que concerne à relevância atribuída pelo público ao noticiário de mortes, de acordo com diferentes perfis de enunciatário, Angrimani (1995, p. 54) afirma que o tema "interessa a todos, igualitariamente, independente do nível cultural ou econômico de cada pessoa". Assim, entre a cobertura feita pela imprensa tida como sóbria e a considerada sensacionalista, há, sobretudo, uma diferença entre as estratégias textuais utilizadas, recobrindo determinados pontos de vista. $\mathrm{O}$ autor se baseia em Baudrillard (1976 apud ANGRIMANI, 1995, p. 56), que toma a morte do outro "saboreada como espetáculo". Quando associada à ausência de um "ente querido", o tema costuma ser vinculado a sentimentos fúnebres, de perda, saudade, dor e inconformismo. Porém, ao estampar as páginas dos jornais, ganha um efeito de sentido de "compensação", de preservação da vida do leitor, já que é o outro que morre no lugar dele. 
Pensamos imediatamente em Bataille e na sua afirmação de que o cadáver impressiona por lembrar aos vivos "a imagem de seu destino". O leitor, então, recebe um choque, imaginando que amanhã poderá ser a vez dele. Mas ao mesmo tempo que se produz este impacto (a morte ilustrada, ampliada, por um recurso de linguagem editorial sensacionalista), vem também o alívio. O jornal atende a uma necessidade inconsciente, onde o cadáver "ilustrado" morre "por procuração" no lugar do leitor. (ANGRIMANI, 1995 , p. 56)

Em relação às diferentes abordagens da morte pelos veículos informativos, Barbosa (2004, p. 3) destaca que, na mídia, o tema se configura como um "espetáculo banal, mesmo que os gestos ritualizados devam ser dramáticos. O que importa são os instantes que antecedem ao desfecho previsível". A tranquilidade do leito da morte "é substituída pela cena pública, onde o excesso é a palavra de ordem" (BARBOSA, 2004, p. 3). Castilho traça algumas características da chamada morte midiática, em que prevalecem o tom de tragédia, o excesso e a dramatização dos fatos:

Essa lógica narrativa é construída no sentido de capturar a adesão do telespectador ou do leitor para a celebração fúnebre. Obedece também aos prazos de produção da televisão e dos jornais. Não há mais tempo para os rituais nem o leito de morte. Em troca, os produtores de notícias reforçam o impacto e o sentido de comoção pública. (CASTILHO, 2005, p. 32)

Outra especificidade da morte midiática, segundo o autor, é o "fascínio que as perdas violentas ou inesperadas, aquelas que tomam de assalto uma trajetória e interrompem ações e projetos de vida, exerce na imprensa" (CASTILHO, 2005, p. 32). Com base em Mouillaud (2002 apud CASTILHO, 2005, p. 33), ele destaca que, nos jornais, os mortos ganham status distintos. O "morto banal e inominável" é o que aparece no noticiário diariamente, anônimo, vítima da violência cotidiana, cujo falecimento importa somente como parte de um balanço de perdas e ganhos. Já o "morto notável" é digno de biografia e de homenagens póstumas. Pode ganhar destaque suficiente para sobrepor outros fatos, chegando a se tornar a única manchete do dia. Além disso, de um assunto único, muitas vezes se desdobra em matérias secundárias. "Enquanto aquele se mantém anônimo nos hospitais e velórios, este é reconduzido ao mundo dos vivos, via meios de comunicação", conclui Castilho (2005, p. 32-33). 


\section{A morte estampada nas capas}

Após o detalhamento da identidade mais abrangente dos chamados jornais "espreme que sai sangue" e alguns apontamentos sobre a morte midiática, torna-se possível examinar como a imprensa brasileira repercutiu o "Massacre de Realengo" nas capas do dia seguinte ao fato. A análise que segue se organiza em um continuum, conforme ilustrado abaixo (Figura 1), das páginas mais distantes às mais próximas do jornalismo dito sensacionalista, em uma gradação qualitativa de efeitos de sentido:

FIGURA 1 - Gradação qualitativa de efeitos de sentido das capas sobre o "Massacre de Realengo" (da esquerda para a direita, das menos às mais apelativas)
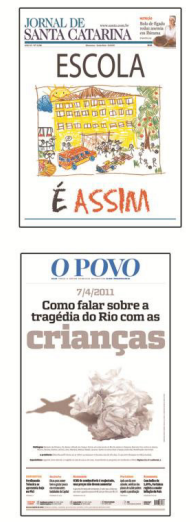
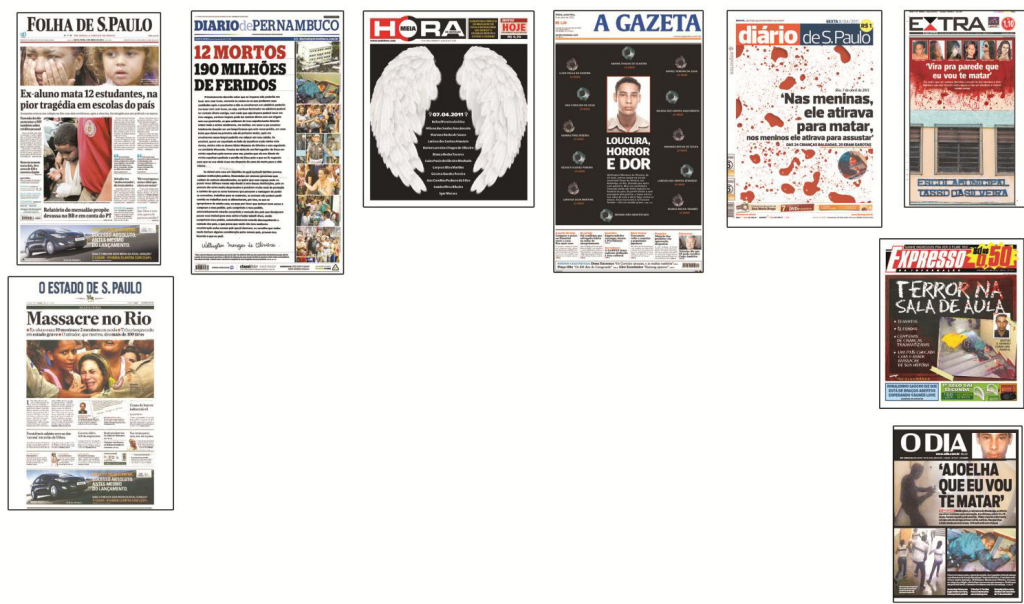

No polo mais moderado, estão o Jornal de Santa Catarina e O Povo, do Ceará. Apesar de não circularem no Sudeste, mas no Sul e no Nordeste do Brasil, respectivamente, os dois veículos romperam as barreiras geográficas e ganharam destaque na internet por suas capas do dia 8 de abril. A repercussão se deveu às alternativas usadas para noticiar o "Massacre de Realengo". Os jornais deixaram de lado a ênfase no factual e a diagramação canônica - com divisão da página em colunas e a fórmula manchete, chamada e fotos - e optaram por uma composição mais temática e sem remissão direta ao episódio. 
FIGURA 2 - Jornal de Santa Catarina

Fonte: Net Papers (2011)

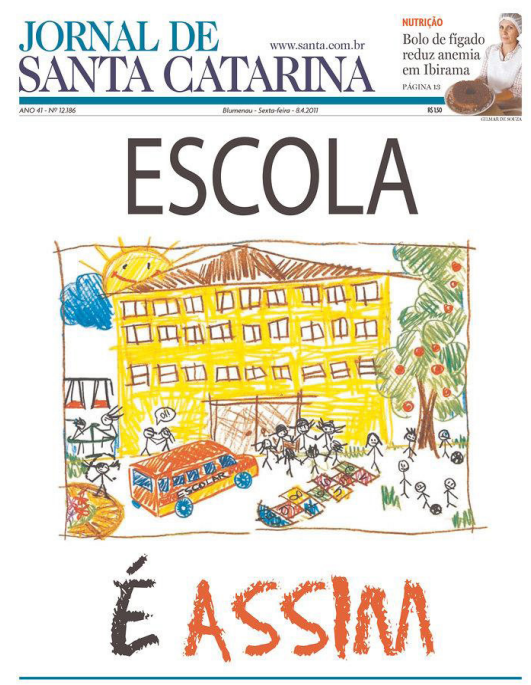

FIGURA 3 - O Povo

Fonte: Net Papers (2011)

\section{O POVO}

$7 / 4 / 2011$

Como falar sobre a tragédia do Rio com as
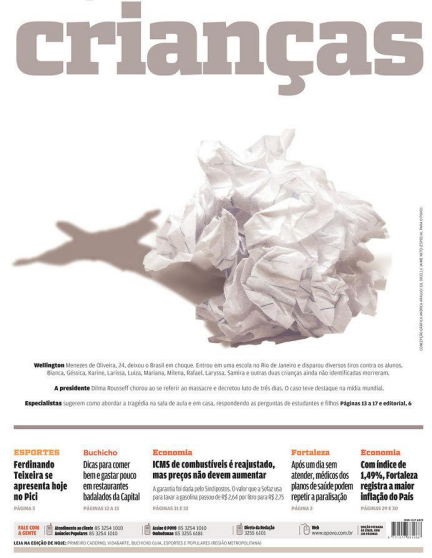
No Jornal de Santa Catarina (Figura 2), uma ilustração em cores vivas ocupa a maior parte da capa. Seus traços remetem a uma pintura feita a lápis de cor ou hidrocor. Um colégio, um ônibus escolar, crianças brincando no pátio e um sol "sorrindo" compõem o desenho. Tais elementos permitem a identificação de uma isotopia ${ }^{7}$ infantil. Em diálogo com a imagem, a manchete "Escola é assim" faz referência a um ambiente alegre, em oposição ao cenário triste da Escola Municipal Tasso da Silveira. Apesar de o massacre não ser mencionado, há uma comparação implícita. O título poderia ser completado por “...e não como o que aconteceu no Rio de Janeiro".

Embora domine a página, o assunto não é a única manchete do dia. No canto superior direito, lê-se uma dica de nutrição: "Bolo de figado reduz anemia em Ibirama". Em ambos os casos, cria-se um efeito de sentido de ensinamento, que também pode ser inferido na manchete e em uma das chamadas de O Povo (Figura 3): "Como falar sobre a tragédia do Rio com as crianças" e "Especialistas sugerem como abordar a tragédia na sala de aula e em casa, respondendo as perguntas de estudantes e filhos".

A capa de $O$ Povo é composta pelas figuras do Cristo Redentor, símbolo carioca, e de uma bolinha de papel, conhecida brincadeira de sala de aula. As imagens, em conjunto com o tema "tragédia", são referências indiretas ao "Massacre de Realengo". A remissão ao episódio também aparece nos conteúdos verbais "Rio" e "7/4/2011", debreagens enuncivas, que criam efeitos de sentido de distanciamento e de verdade histórica.

O componente mais factual da cobertura aparece somente na chamada, em fonte reduzida, que dá informações sobre o massacre, a decisão da presidente Dilma Rousseff de decretar luto e a repercussão do caso na mídia internacional. Da mesma forma que no Jornal de Santa Catarina, a notícia domina a página, mas não é o único assunto da capa. A edição de $O$ Povo traz, ainda, manchetes regionais, com temas como esporte e economia.

\footnotetext{
${ }^{7}$ Chama-se isotopia a reiteração de traços semânticos ao longo do texto. Com função de redundância, a operação garante coerência semântica, determina um plano de leitura (cf. FIORIN, 2011).
} 
Observa-se que nem o Jornal de Santa Catarina nem O Povo exploram o caráter apelativo inerente ao "Massacre de Realengo" por um detalhamento do caso, mas sim pelo seu impacto sobre as crianças. Os dois jornais preocupam-se em apresentar maneiras de "poupá-las". O primeiro mostra que o ambiente escolar deve ser lúdico, alegre e divertido. O segundo recorre a especialistas para ensinar como abordar o tema. Essa ideia de ensinamento, aliada à diagramação fugindo ao canônico de jornais diários, aproxima as páginas ao jornalismo de revista. Segundo Vilas Boas, essa vertente costuma ter capas com grande apelo estético e se dedicar a reflexões aprofundadas sobre os assuntos noticiados:

[a revista] preenche os vazios informativos deixados pelas coberturas dos jornais, rádio e televisão. Além de visualmente mais sofisticada, outro fator a diferencia sobremaneira do jornal: o texto. Com mais tempo para extrapolações analíticas do fato, as revistas podem produzir textos mais criativos, utilizando recursos estilísticos geralmente incompatíveis com a velocidade do jornalismo diário. (VILAS BOAS, 1996, p. 9)

Uma proposta diferente é encontrada nos paulistanos Folha de S. Paulo (Figura 4) e O Estado de S. Paulo (Figura 5), reconhecidos por sua alta credibilidade e representatividade no jornalismo brasileiro respectivamente, terceiro e quarto maiores jornais impressos do país de circulação paga, por ano $(A N J, 2015) .{ }^{8} \mathrm{Na}$ cobertura do "Massacre de Realengo", as capas dos dois veículos apresentaram abordagens muito semelhantes, o que possibilitou o agrupamento de ambas em um mesmo ponto do continuum proposto por este trabalho.

${ }^{8}$ Disponível em: <http://goo.gl/nHMxYm>. Acesso em: 9 mai. 2016. 
FIGURA 4 - Folha de S. Paulo

Fonte: Net Papers (2011)

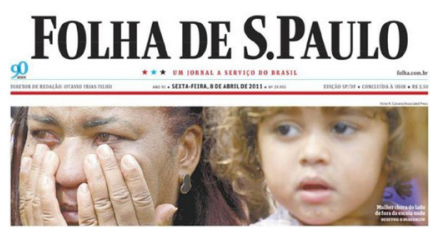

Ex-aluno mata 12 estudantes, na pior tragédia em escolas do país

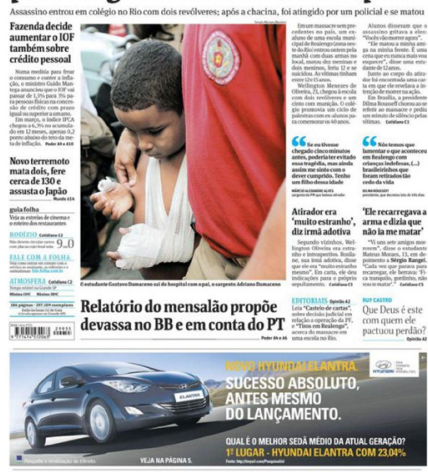

FIGURA 5- O Estado de S. Paulo

Fonte: Net Papers (2011)
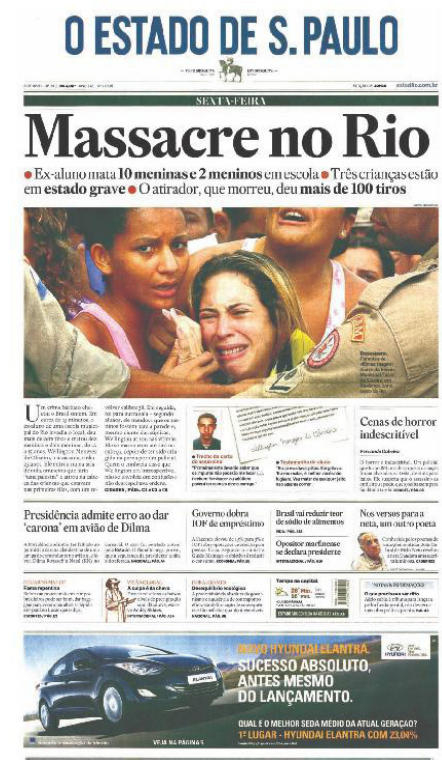
Um primeiro olhar já permite a identificação de elementos comuns às duas capas. Além da diagramação canônica - equilibrando conteúdos verbais e visuais -, ambos os veículos recorrem ao tema da comoção nas fotos de alto de página, que retratam mulheres chorando. Na Folha, há uma segunda fotografia, em que um dos alunos feridos é amparado por um bombeiro. Segundo a legenda, é o pai do menino. A figura do bombeiro que ampara também está presente na foto do Estadão. Contribui, ainda, para a criação de uma identidade comum às duas capas a publicação do mesmo anúncio, do mesmo tamanho, no pé das duas páginas.

As manchetes trazem o lide. ${ }^{9} \mathrm{O}$ título da Folha detalha e qualifica o episódio: "Ex-aluno mata 12 estudantes, na pior tragédia em escolas do país". No subtítulo, são apresentados o local e o desfecho da história: "Assassino entrou em colégio no Rio com dois revólveres; após a chacina, foi atingido por um policial e se matou". O título do Estadão também caracteriza e localiza o fato: "Massacre no Rio". Mas sua estrutura condensada, nominal, impacta ${ }^{10}$ mais o leitor do que se a ação fosse desdobrada verbalmente. O resumo da ação vem no subtítulo: "Ex-aluno mata 10 meninas e 2 meninos em escola. Quatro crianças estão em estado grave. O atirador, que morreu, deu mais de 100 tiros" (grifos do autor). O uso do negrito ressalta informações que, por si só, são impactantes: o número de mortos e de tiros e o estado dos feridos.

No título da Folha e no subtítulo do Estadão, o verbo "matar" é usado no presente, para relatar um fato que aconteceu no dia anterior à publicação do jornal. Trata-se de uma embreagem enunciativa temporal. O recurso, amplamente usado no discurso jornalístico, cria um efeito de sentido de aproximação do leitor, no caso, com o momento do assassinato. Outro aspecto presente nas duas manchetes é a menção à morte de Wellington. Em sua discussão sobre o sensacionalismo, Angrimani (1995, p. 56) atenta para a morte noticiada como possibilidade transgressora e proposta de advertência. "Transgressora, porque o jornal

\footnotetext{
${ }^{9}$ Chama-se lead ("lide") a abertura de uma notícia, que relata as principais informações do fato narrado. Deve responder a seis perguntas básicas: O quê? Quem? Quando? Onde? Como? Por quê? (cf. MARTINS, 1997).

${ }^{10}$ Zilberberg (2006, p. 171) define impacto como "o significado inapreciável de toda exclamação", uma "superlatividade", resultante da união entre uma tonicidade forte e um andamento acelerado, característicos dos processos de condensação.
} 
'mata' alguém que o leitor gostaria de ter ele mesmo matado [...]'. Advertência, pressupondo a existência de regras de comportamento que, desobedecidas, levam a uma punição. Aqui, tem-se a inscrição no enunciado de um valor eufórico (positivo) da morte em uma acepção de "justiça feita", implicado na punição do algoz.

Os dois jornais fazem referência ao policial que baleou Wellington. O PM é o recobrimento semântico do que, do ponto de vista da narrativa do atirador, configura-se como antissujeito, actante com papel de obstaculizar que o sujeito da ação Wellington entre em conjunção com o objeto-valor "matar os alunos". Quanto à narrativa dos alunos, a figura do PM funciona como adjuvante, actante que ajuda na conjunção com o objeto-valor "vida". A Folha traz, inclusive, um depoimento dele: "me sinto com o dever cumprido".

Ambos os veículos constroem uma isotopia religiosa, ao citarem a carta deixada por Wellington antes de se matar. O Estadão reproduz a imagem de um trecho - o que cria maior efeito de verdade -, em que aparecem os temas "impuros", "fornicador" e "adúltero". A Folha destaca que a carta continha indicações para o sepultamento do atirador e traz um artigo do colunista Ruy Castro intitulado "Que Deus é este com quem ele pactuou perdão?”. Nas duas capas, tem-se o fanatismo religioso como destinador-manipulador que leva o destinatário-manipulado Wellington a dever/querer assassinar os alunos.

Mais uma semelhança é a presença nos dois jornais de uma pluralidade de vozes. O Estadão traz a opinião do ex-deputado federal e colunista Fernando Gabeira, de testemunhas e de pessoas que conheciam Wellington. A Folha dá voz ao PM, à presidente Dilma Rousseff e à irmã adotiva do atirador. Em alguns momentos, os depoimentos são em discurso direto, debreagem interna, que reforça o efeito de verdade frequentemente buscado no discurso jornalístico. Também há em ambos uma caracterização de Wellington como "introspectivo". Por fim, observa-se nas capas um equilíbrio entre a cobertura do massacre e a de outros assuntos, com destaque para temas como política, economia, mundo e cultura. Há até mesmo outra manchete comum aos dois jornais, referente ao aumento do IOF.

A análise mostra que tanto o Estadão quanto a Folha procuram apresentar uma cobertura extensa do "Massacre de Realengo", posicionamento necessário à manutenção da credibilidade dos jornais. Os veículos descrevem o episódio, ouvem diferentes versões, discutem 
o assunto no editorial e em artigos de opinião. Com ênfase no factual, as manchetes buscam certo distanciamento do caso. Porém, ao debruçar-se sobre as páginas, é possível identificar marcas textuais que exploram o apelo passional inerente ao fato.

Na sequência da gradação está o Diário de Pernambuco (Figura 6). Exclusiva sobre o massacre, a capa do jornal do Nordeste foi uma das que mais ganharam destaque na cobertura. O primeiro choque já se dá no título da manchete: "12 mortos, 190 milhões de feridos". O impacto é causado, em parte, pela frase nominal, em fonte ampliada e em caixa alta. Também contribui para arrebatar o leitor a relação semissimbólica - correlação entre termos de uma categoria do plano de expressão e termos de uma categoria do plano de conteúdo (BARROS, 2005, p. 85) - estabelecida entre a fonte em vermelho e as vítimas fatais e a fonte em preto e a população brasileira, em luto pela tragédia.

FIGURA 6 - Diario de Pernambuco

Fonte: Net Papers (2011)

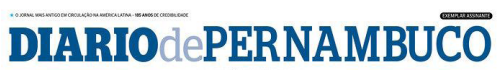

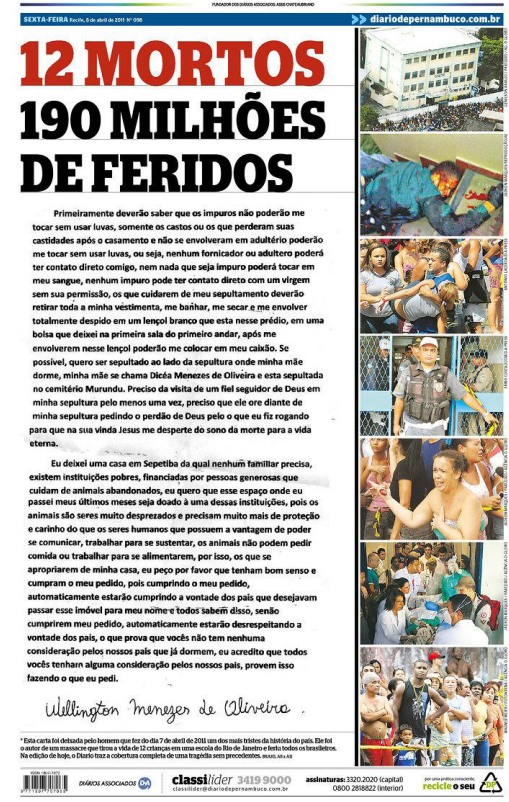


Junto ao título, a sequência de fotos - além de criar uma narrativa - constrói uma isotopia da comoção. São retratados a multidão em torno da escola, um homem amparando uma estudante, o policial adjuvante, uma mulher chorando, a equipe de resgate recebendo as vítimas e, novamente, a multidão que acompanha o caso. A chamada, no pé da página, retoma o tema, ao destacar que o massacre "feriu todos os brasileiros". As fotografias também contribuem para a construção de um efeito de sentido de verdade.

Essa veracidade é reforçada pela reprodução da imagem completa da carta deixada por Wellington antes de se matar, assinada de próprio punho. Assim, o leitor conhece a caligrafia do atirador. Além disso, há a ocorrência de debreagem interna, discurso direto. No documento, em primeira pessoa, ele explica passo a passo como deve ser sepultado. $\mathrm{O}$ jornal usa, ainda, uma debreagem enunciva temporal na chamada, para criar um efeito de sentido de marco histórico, com "7 de abril de 2011" em vez de "ontem".

Da mesma maneira que na Folha e no Estadão, a isotopia religiosa está presente no Diario de Pernambuco. Mas, aqui, ela fica mais enfatizada, devido à publicação na íntegra da carta, que contém temas como "impuros", "castos", "adultério", "virgem" e "fiel" e figuras como "Deus" e "Jesus". Mais uma vez, identifica-se o fanatismo religioso como destinador-manipulador da ação de Wellington.

Por fim, também como na Folha e no Estadão, o valor eufórico da morte em relação ao suicídio de Wellington aparece na capa do Diário de Pernambuco. Mas o veículo o evidencia com a publicação de uma foto do cadáver. Não resta dúvida ao leitor: como ele pode conferir, o algoz foi punido. Outra marca desse valor eufórico está no título da manchete, que não contabiliza Wellington entre as vítimas. Deve haver comoção sim, mas apenas pelos doze alunos assassinados e não pela morte do autor do crime.

O próximo jornal do continuum causou surpresa no dia seguinte ao "Massacre de Realengo". Muitos leitores poderiam esperar uma capa do tipo "espreme que sai sangue" do carioca Meia Hora (Figura 7). O emprego de uma linguagem coloquial, com grandes doses de humor, além do frequente investimento em apelos eróticos, são marcas do veículo. Originalmente criado para atender às classes $\mathrm{D}$ e $\mathrm{E}$, a publicação se expandiu para outros públicos, devido à irreverência de suas primeiras páginas. Em relação à cobertura da violência, como destaca Soares 
(2009, p. 89), desde o nascimento do Meia Hora "o público de jornais mais tradicionais do Rio de Janeiro, como O Globo e o Jornal do Brasil, viu-se, não raramente, escandalizado com a abordagem escolhida pelo meio". Mas, na cobertura em questão, as imagens de cadáveres e o foco no desespero de parentes e amigos das vítimas deram lugar a uma primeira página sóbria. Um fundo preto contrasta com o branco de asas de anjo. As figuras emolduram uma lista com o nome completo de cada um dos doze alunos assassinados. No topo, apenas uma data, envolta por cruzes: "07.04.2011".

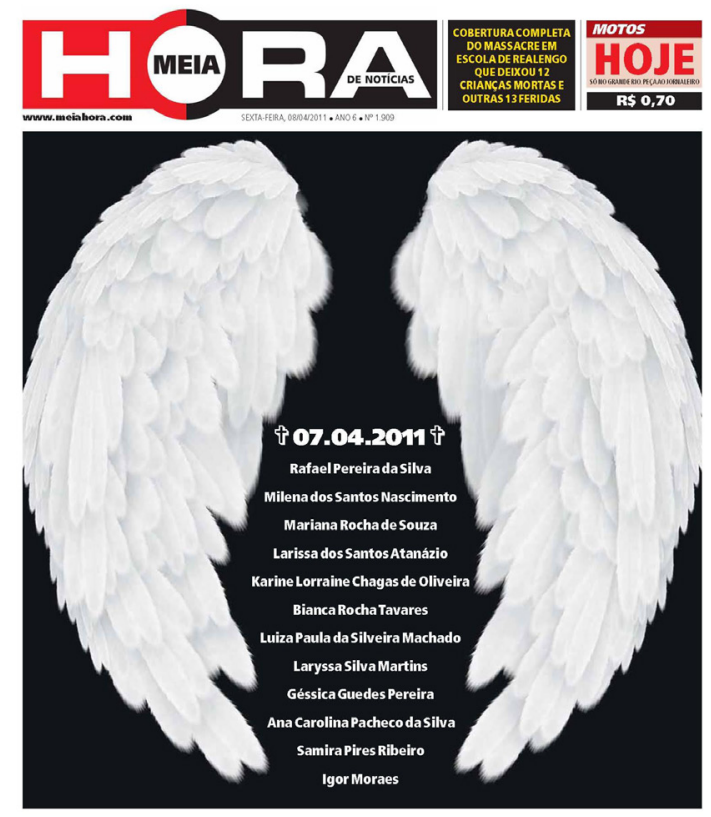

As asas - que remetem a temas como proteção e pureza - e as cruzes dispostas como a inscrição de um túmulo marcam, novamente, uma isotopia religiosa. Mas, aqui, ela não se refere ao fanatismo que pode ter motivado a ação de Wellington. No Meia Hora, a religião está associada ao divino. Os mortos foram acolhidos por anjos no céu, onde estão protegidos e alcançaram a "vida eterna", como prega o cristianismo. 
Pode-se depreender também uma comparação entre a inocência das jovens vítimas e a pureza angelical.

A opção pela data no lugar do advérbio "ontem", debreagem enunciva temporal, cria, conforme já apontado, um efeito de sentido de verdade histórica. O "Massacre de Realengo", por sua proporção e ineditismo, se torna um marco no Brasil. Uma segunda interpretação possível se refere à proximidade do leitor do Meia Hora ao episódio. O enunciador do veículo pressupõe que seu enunciatário identifique o caso a partir de poucos elementos, sendo desnecessário "falar" muito. Esse sentido é reafirmado pela presença do conteúdo factual apenas em um pequeno quadro no canto superior direito da página, quase confundido com o preço do jornal ou um selo promocional: "Cobertura completa do massacre em escola de Realengo que deixou 12 crianças mortas e outras 13 feridas".

Outra estratégia interessante adotada pelo Meia Hora é a publicação de uma lista com os nomes e sobrenomes dos adolescentes assassinados. Ao figurativizar as vítimas nomeando cada uma, cria-se um efeito de aproximação delas com o leitor. Não foram alunos quaisquer que morreram, mas sim a Samira Pires Ribeiro, o Igor Moraes, etc..

$\mathrm{Na}$ conjugação desses elementos, apesar de não fazer nenhuma referência direta ao tema assassinato, a capa do Meia Hora exerce um grande apelo emocional. A exclusividade do assunto, o excesso de preto e o uso de poucos elementos verbais e imagens criam efeitos de sentido de luto, sobriedade, silêncio, em homenagem às vítimas. É como se o jornal se comovesse junto com os parentes e amigos dos mortos e, também, com o público.

No ponto intermediário da gradação feita com as capas sobre o "Massacre de Realengo", localiza-se A Gazeta (Figura 8), do Espírito Santo. Na primeira página do jornal, observa-se um equilíbrio entre elementos que criam um efeito de sentido de distanciamento do episódio e elementos característicos do estilo enunciativo sensacionalista. 
FIGURA 8 - $A$ Gazeta

Fonte: Net Papers (2011)

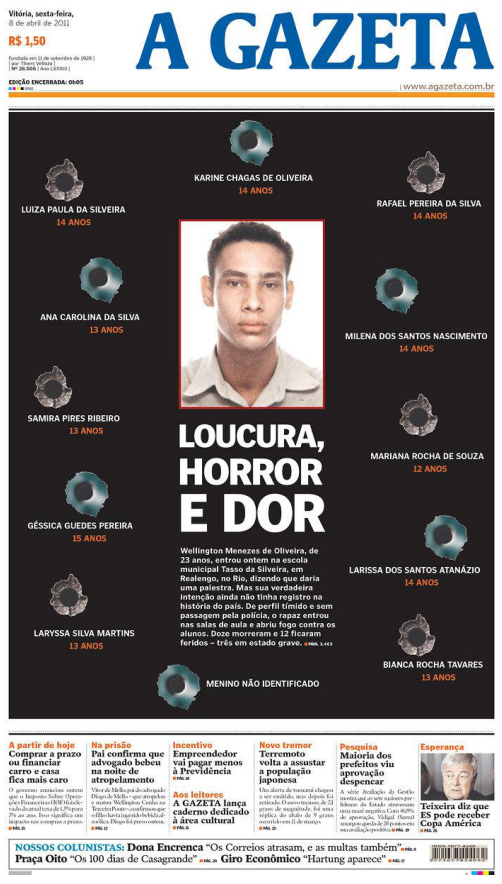

Como no Meia Hora, um fundo preto ocupa a maior parte da capa de $A$ Gazeta. Mas sua uniformidade é quebrada pelas imagens de buracos de bala, figuras que concretizam o tema assassinato. Os efeitos de sentido de luto, sobriedade e silêncio reiterados pela cor na página analisada anteriormente dão lugar à morte associada à violência, ao terror. Essa ideia é reforçada pelo impactante título da manchete, condensado e em caixa alta: "Loucura, horror e dor". A frase traz, na ordem, uma possível motivação para a execução do massacre, o cenário da escola diante da ação e sua consequência para os envolvidos.

Os disparos retratados parecem perfurar uma superfície de metal. A conjugação desses elementos à foto central de Wellington pode remeter a um estande de tiro, em que o atirador é o alvo. Os buracos de bala funcionam, ainda, como marcadores para enumerar cada um dos assassinados. E, se no Meia Hora o leitor teve acesso aos nomes e sobrenomes das vítimas, $A$ Gazeta traz uma informação adicional, as 
idades. Esse nível maior de figurativização dos mortos aproxima mais o enunciatário do jornal ao fato narrado.

A capa enfatiza o sujeito do fazer, dando a Wellington status de um "morto notável". No centro da página, a foto $3 \times 4$ "encara" o público. É o retrato do assassino, rodeado pelas vítimas. O foco da chamada também é na figurativização do atirador:

Wellington Menezes de Oliveira, de 23 anos, entrou ontem na escola municipal Tasso da Silveira, em Realengo, no Rio, dizendo que daria uma palestra. Mas sua verdadeira intenção ainda não tinha registro na história do país. De perfil tímido e sem passagem pela polícia, o rapaz entrou nas salas de aula e abriu fogo contra os alunos.

A oposição entre os trechos "dizendo que daria uma palestra" e "verdadeira intenção" marca uma surpresa do enunciador do jornal diante da ação de Wellington. Esse efeito de sentido é reafirmado pela caracterização do ex-aluno como um "rapaz", "de perfil tímido e sem passagem pela polícia". Diante desse quadro, somente a loucura, conforme citado no título da manchete, justificaria tal ato de violência. Assim, em $A$ Gazeta, é a insanidade o destinador-manipulador que leva Wellington a dever/querer matar os alunos.

Ao mesmo tempo em que explora marcas textuais e apelos estéticos característicos do jornalismo dito sensacionalista, A Gazeta procura cumprir o papel de um veículo mais moderado. Da mesma forma que a Folha e o Estadão, o jornal traz o factual e destina espaço na página a manchetes sobre outros assuntos. Além disso, apesar de focar na figura de Wellington, a cobertura não se restringe a tachá-lo como vilão. Em vez de dar destaque a sua morte, o jornal busca explicar o que o levou a cometer o crime.

No percurso das capas, a do Diário de S. Paulo (Figura 9), tende para o polo mais apelativo. As manchas vermelhas que "sujam" o fundo branco da página e a imagem do cadáver de Wellington ensanguentado remetem imediatamente ao jornalismo "espreme que sai sangue". A posição da foto, no canto inferior direito, explicita o desfecho do episódio, com a morte do atirador. Novamente, a imprensa ressalta a sanção negativa do algoz. 


\section{FIGURA 9 - Diário de S. Paulo}

Fonte: Net Papers (2011)

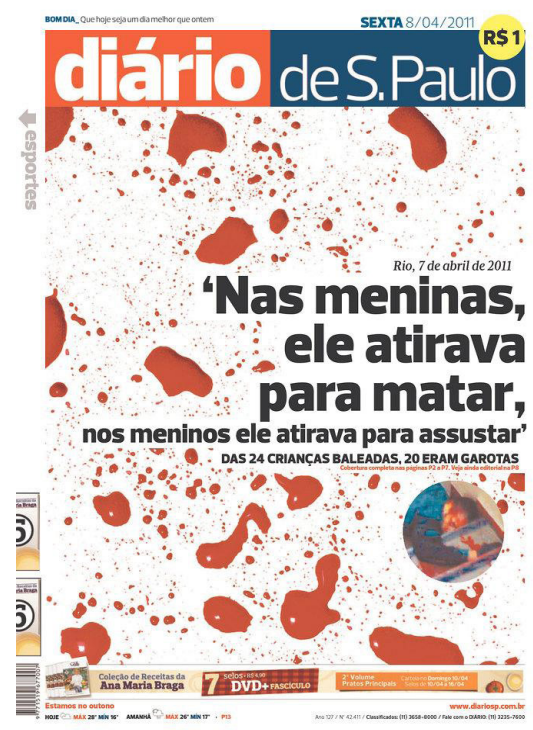

A manchete exclusiva explora exacerbadamente o apelo inerente ao fato. No título, a debreagem interna e a ênfase na performance do sujeito do fazer criam um efeito de sentido de verdade: "Nas meninas, ele atirava para matar, nos meninos ele atirava para assustar"'. Trata-se do depoimento de uma das testemunhas, que conta como o atirador agiu. Segundo Fiorin, (2011, p. 33), "um jornal sensacionalista, ao contar um assassinato, narra em geral a performance: como foi o crime, quem o realizou, quem era a vítima, etc.". Com a adoção de tais estratégias, o leitor acompanha "minuto a minuto" o caso, como se estivesse presente na cena. O jornal opta, ainda, pela debreagem enunciva temporal "7 de abril de 2011", para registrar a importância do massacre, um marco na história do país.

A opção por uma fonte ampliada na primeira parte do título destaca a preferência de Wellington por assassinar alunas. A especificidade é retomada no subtítulo: "Das 24 crianças baleadas, 20 eram garotas". As figuras "meninas", "meninos" e "garotas" constroem uma isotopia sexual. Esses elementos de expressão e de conteúdo evidenciam a hipótese de que $o$ atirador escolheu as vítimas pelo gênero. Ou seja, a misoginia passa a ser o destinador-manipulador da ação de Wellington, e não mais o fanatismo ou a insanidade. 
Como no Meia Hora, o Diário de S. Paulo busca compartilhar o mesmo sentimento do público em relação ao massacre. No canto superior esquerdo da página, lê-se a frase: "BOM DIA_Que hoje seja um dia melhor que ontem", que explicita um envolvimento passional. $\mathrm{O}$ veículo "fala" com o leitor, se comove junto com ele e deseja, como ele, que dias melhores venham. Esse efeito de sentido de aproximação, bem como o foco dado pelo jornal ao aspecto sanguinário do caso, mobiliza o enunciatário emocional e sensorialmente.

Chegando ao final do continuum, três jornais populares cariocas se agrupam no polo mais apelativo. São eles: Extra (Figura 10), Expresso (Figura 11) e $O$ Dia (Figura 12). Suas capas exploram à exaustão marcas textuais e apelos estéticos característicos do jornalismo dito sensacionalista. Como que em uma compilação de todas as estratégias descritas até aqui, nas páginas a seguir, a morte é apresentada de forma "nua e crua" para o leitor. A iconização é utilizada de modo a explorar o aspecto brutal do episódio.

FIGURA 10 - Extra

Fonte: Net Papers (2011)

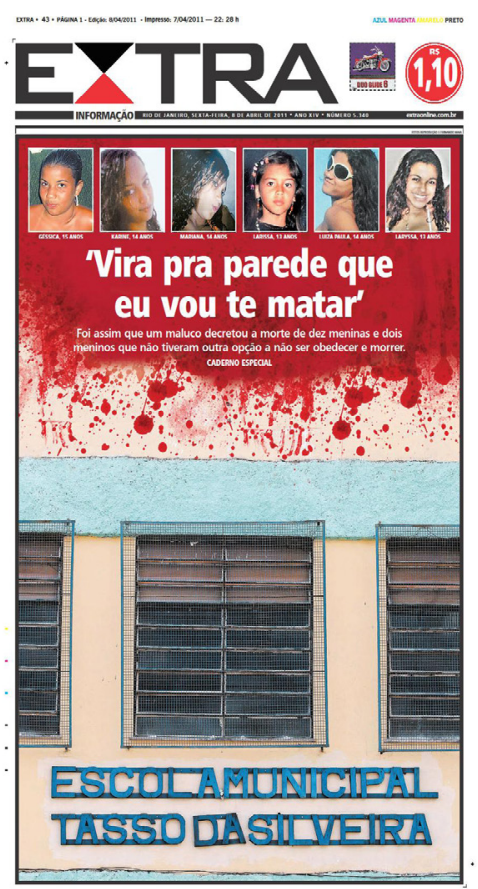


FIGURA 11 - Expresso

Fonte: Net Papers (2011)
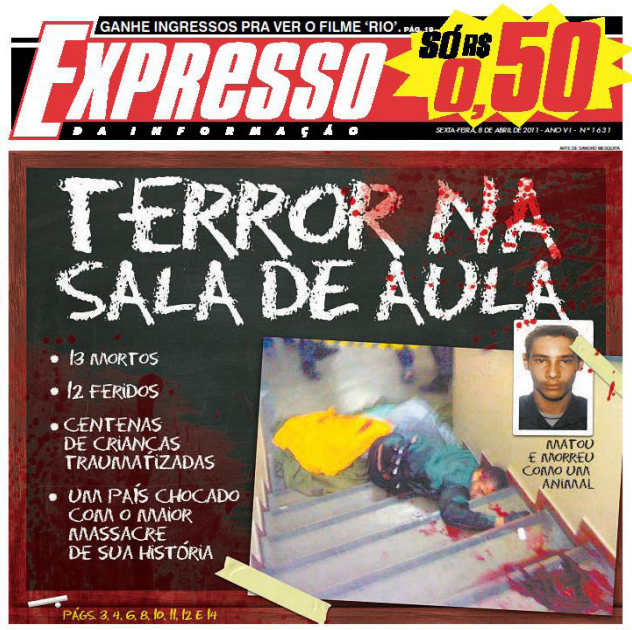

RONALDINHO GAÚCHO DIZ QUE ESTÁ DE BRAÇOS ABERTOS ESPERANDO VÁGNER LOVE

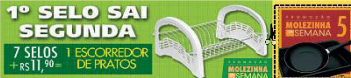

\section{FIGURA 12 - O Dia}

Fonte: Net Papers (2011)

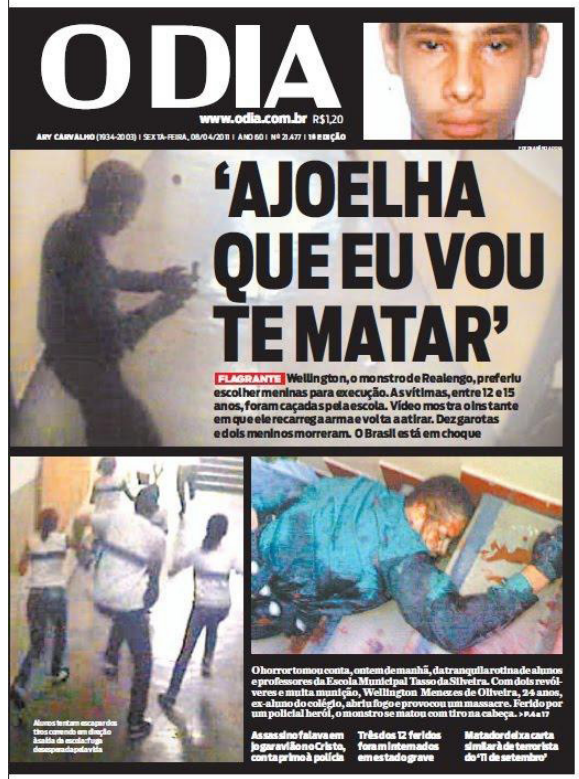


Uma foto da fachada da Escola Municipal Tasso da Silveira ocupa toda a página do jornal Extra. A disposição da imagem dá uma visão ampliada do local do massacre e transporta o leitor até lá. São criados efeitos de sentido de verdade e de aproximação. Na parte superior, uma mancha vermelha cobre parcialmente a fotografia. Sobre os dois planos, estão posicionados lado a lado os retratos de seis das dez alunas assassinadas. Os elementos visuais criam uma narrativa. É o sangue das vítimas escorrendo pela fachada.

As adolescentes retratadas parecem posar para o leitor. O subtítulo enfatiza o número maior de vítimas do gênero feminino: "morte de dez meninas e dois meninos". Mais uma vez, identifica-se uma isotopia sexual. Da mesma maneira que no Diário de S. Paulo, a capa do Extra toma a misoginia como destinador-manipulador da ação de Wellington. Outro aspecto relevante são as legendas. Como no Meia Hora e em $A$ Gazeta, cria-se uma aproximação entre o público e as vítimas. Mas o Extra divulga seus rostos e idades, além de referir-se a elas pelo primeiro nome. Com a estratégia, estabelece-se uma relação mais íntima, já que é comum chamar pelo prenome apenas pessoas com quem se tem um grau de proximidade maior.

O título da manchete, tal qual o do Diário de S. Paulo, é em discurso direto: "'Vira pra parede que eu vou te matar"'. No entanto, dessa vez, dá-se voz não a uma testemunha do crime, mas a Wellington. A ênfase na performance do sujeito do fazer, nesse caso, é ainda mais impactante. O leitor toma conhecimento do que o próprio algoz disse enquanto atirava nos alunos. Esse efeito de sentido é reforçado pela expressão "foi assim", no subtítulo. Também é interessante observar no subtítulo a caracterização de Wellington como insano e das vítimas como indefesas: "Foi assim que um maluco decretou a morte de dez meninas e dois meninos que não tiveram outra opção a não ser obedecer e morrer".

Na primeira página do Expresso, sobrepondo-se à imagem de um quadro-negro, mais uma vez, aparecem manchas vermelhas. $\mathrm{O}$ aspecto sanguinário do massacre é reforçado pela foto do cadáver de Wellington, ampliada e com um enquadramento que valoriza o rastro de sangue deixado na escada. O valor eufórico da morte em relação ao suicídio do atirador é retomado. Há também uma foto $3 \times 4$ do assassino, que "encara" o leitor, como em A Gazeta.

A capa é marcada por uma isotopia escolar, construída no plano de conteúdo visual pelas figuras do quadro-negro, do giz e da fita adesiva; 
no verbal pela figura "sala de aula"; e no plano de expressão pela fonte usada na manchete, simulando uma escrita a giz. O título "Terror na sala de aula" qualifica o episódio. Na sequência, o caso é narrado em tópicos: "13 mortos", "12 feridos", "centenas de crianças traumatizadas", "um país chocado com o maior massacre de sua história”. Observa-se uma progressão, dos diretamente aos indiretamente afetados, na ordem: mortos, feridos, testemunhas, população brasileira. As frases nominais e em caixa alta e os temas "terror", "trauma" e "choque" também contribuem para a construção de um impacto na página, que arrebata o leitor.

O Expresso, como os demais jornais analisados, enfatiza a punição do algoz. Mas, nesse caso, identifica-se um posicionamento diferente do enunciador. $\mathrm{Na}$ legenda das fotos de Wellington, o atirador é comparado a um animal, em uma acepção negativa. Por outro lado, seu suicídio é contabilizado no número de mortes. Seu impulso animalesco o transformou em (mais) uma vítima do próprio ato. Assim, Wellington é tomado como culpado e vítima ao mesmo tempo.

Entre as capas que compõem o último polo da gradação, a de $O$ Dia é a que melhor exemplifica o jornalismo "espreme que sai sangue". Como em A Gazeta, o preto que cobre o fundo da página do jornal remete à morte associada à violência e ao terror, e não ao luto, à sobriedade e ao silêncio depreendidos do Meia Hora. Esse efeito de sentido é criado pelo diálogo entre o componente cromático e as imagens que dominam a capa. Além da foto do cadáver de Wellington, punição do algoz, e do assassino "encarando" o leitor, são reproduzidos registros das câmeras de segurança da escola, que conduzem o público ao momento exato da ação do atirador. A ênfase na performance é explorada ostensivamente.

A predileção por narrar a performance e o consequente efeito de sentido de verdade criado continuam no título da manchete: "Ajoelha que eu vou te matar"'. A estratégia, debreagem interna, é a mesma usada pelo Extra, proporcionando ao leitor a sensação de ouvir Wellington durante a execução do massacre. Essa ideia de fazer o leitor "reviver os fatos" é reforçada nas chamadas. Na primeira, o tema "flagrante", em caixa alta e realçado pelo vermelho, alerta: "Vídeo mostra o instante em que ele recarrega a arma e volta a atirar". A embreagem enunciativa temporal, com o uso dos verbos "mostrar", "recarregar" e "voltar" no presente fazendo referência ao passado, cria um efeito de sentido de aproximação. O mecanismo também aparece na legenda: "Alunos tentam escapar dos tiros correndo em direção à saída da escola: fuga desesperada pela vida" (grifo do autor). 
Na segunda chamada, no canto inferior direito da página, como se o enunciatário ainda não tivesse informações suficientes para "visualizar" o episódio, o massacre ganha um nível maior de concretização. $\mathrm{O}$ "horror" tomou conta da escola, quando o "monstro" Wellington entrou no colégio "com dois revólveres" e "muita munição" e, após ser ferido por um policial, se matou "com tiro na cabeça". O trecho também faz referência ao PM adjuvante dos alunos, caracterizado como "herói”. É interessante notar também como se dá a escolha vocabular nesse caso, denunciando uma visão subjetiva e passional.

Para encerrar, $O$ Dia apresenta diferentes motivações possíveis para a execução do crime. Na primeira, o destinador-manipulador que leva o sujeito da ação Wellington a querer/dever matar os alunos é a misoginia, expressa pela isotopia sexual construída pelos trechos "preferiu escolher meninas para a execução" e "dez garotas e dois meninos morreram". Na segunda, o destinador-manipulador é o fanatismo religioso, concretizado pela isotopia do terrorismo - pregado por grupos religiosos fundamentalistas - presente nas chamadas menores no pé da página: "Assassino falava em jogar avião no Cristo, conta primo à polícia" e "Matador deixa carta similar à de terrorista do "11 de setembro"".

Concluída esta etapa da análise, cabe ressaltar que, apesar de alguns veículos terem sido agrupados em um mesmo ponto da linha do continuum proposto, esta pesquisa não desconsidera as particularidades de cada cobertura e as inflexões decorrentes dessas diferenças. Assim, por exemplo, embora a Folha de S. Paulo e O Estado de S. Paulo ocupem uma posição comum, em um nível mais profundo, é possível identificar dessemelhanças que tornam o segundo jornal ligeiramente mais impactante que o primeiro. Porém, ao apresentar uma gradação qualitativa de efeitos de sentido tomada de forma mais ampla, este trabalho busca, sobretudo, explicitar uma certa permeabilidade entre os estilos moderado e sensacionalista. A seguir, a análise de $O$ Globo permitirá uma reflexão mais aprofundada sobre o assunto.

\section{O lugar de $\boldsymbol{O}$ Globo}

Após o agrupamento e a disposição no continuum das onze capas analisadas, $O$ Globo ganha um tratamento especial. O objetivo é identificar o lugar ocupado pelo jornal entre os polos mais moderado e mais apelativo da gradação proposta. Será que, na repercussão do 
"Massacre de Realengo" na primeira página, o veículo se aproximou mais de um discurso sóbrio, como o esperado para o seu perfil de enunciador, ou acabou se rendendo a uma cobertura sensacionalista? Um exame minucioso da capa ajudará a responder a pergunta.

Uma foto central ocupa a maior parte da capa de $O$ Globo, retratando uma criança amparada por um adulto. A legenda esclarece que se trata de uma das sobreviventes, Jady Lima, de 12 anos, abraçada pela mãe. No alto da página, há outras três imagens, na sequência: um frame de um vídeo publicado na internet, em que uma aluna foge da escola, suja de sangue; a tão divulgada foto do cadáver de Wellington; e a figura do policial que baleou o atirador, "impedindo uma tragédia maior", conforme destaca a legenda. As quatro fotos concretizam, respectivamente, os temas comoção, desespero, suicídio e heroísmo, todos inerentemente apelativos. Nota-se, ainda, um forte contraste no vermelho das duas primeiras fotos do alto da página, cor que se sobressai em relação aos demais elementos.

FIGURA 13 - O Globo

Fonte: Net Papers (2011)

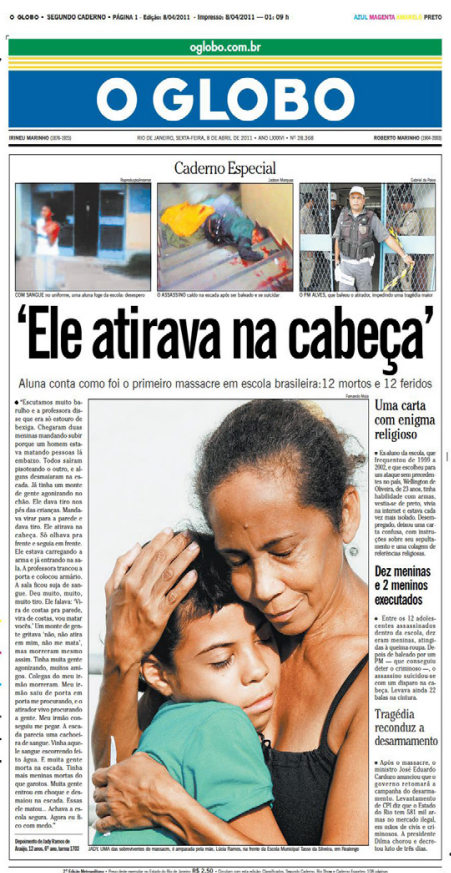


Para além das imagens, $O$ Globo mantém uma diagramação canônica, em colunas, buscando equilibrar os conteúdos verbais e visuais na capa, exclusiva sobre o assunto. Porém, ao contrário do que se pode imaginar em um primeiro olhar, a coluna da esquerda não é um lide factual, mas sim um depoimento de Jady, que descreve detalhadamente o que ocorreu na escola. O relato é antecipado no título da manchete, em discurso direto, debreagem interna: "“Ele atirava na cabeça". O subtítulo chama para o testemunho: "Aluna conta como foi o primeiro massacre em escola brasileira". Há uma grande ênfase na performance do atirador e uma iconização que exacerba o dramático. Mais do que em qualquer jornal descrito anteriormente, o relato da menina transporta o leitor até o momento do crime. É como se ele mesmo estivesse lá, acompanhando toda a ação de Wellington:

\begin{abstract}
"Escutamos muito barulho e a professora disse que era só estouro de bexiga. Chegaram duas meninas mandando subir porque um homem estava matando pessoas lá embaixo. Todos saíram pisoteando o outro, e alguns desmaiaram na escada. Já tinha um monte de gente agonizando no chão. Ele dava tiro nos pés das crianças. Mandava virar para a parede e dava tiro. Ele atirava na cabeça. Só olhava pra frente e seguia em frente. Ele estava carregando a arma e já entrando na sala. A professora trancou a porta e colocou armário. A sala ficou suja de sangue. Deu muito, muito, muito tiro. Ele falava: 'Vira de costas pra parede, vira de costas, vou matar vocês.' Um monte de gente gritava 'não, não atira em mim, não me mata', mas morreram mesmo assim. Tinha muita gente agonizando, muitos amigos. Colegas do meu irmão morreram. Meu irmão saiu de porta em porta me procurando, e o atirador vivo procurando a gente. Meu irmão conseguiu me pegar. A escada parecia uma cachoeira de sangue. Vinha aquele sangue escorrendo feito água. E muita gente morta na escada. Tinha mais meninas mortas do que garotos. Muita gente entrou em choque e desmaiou na escada. Essas ele matou... Achava a escola segura. Agora eu fico com medo."
\end{abstract}

No depoimento de Jady, mais uma vez há um apelo passional, com a concretização do tema desespero em trechos como "todos saíram pisoteando o outro" e "já tinha um monte de gente agonizando no chão". 
A figura sangue aparece em diversos momentos, como em "a escada parecia uma cachoeira de sangue" e "vinha aquele sangue escorrendo feito água". Jady se refere constantemente aos atos de matar e morrer. Há também várias referências à ação de Wellington, como "ele atirava na cabeça", "deu muito, muito, muito tiro", entre outras. Quanto ao plano de expressão verbal, as frases curtas e justapostas também contribuem para impactar o leitor, estabelecendo um ritmo acelerado de leitura.

Vale destacar que Jady não é uma testemunha qualquer do episódio. Após o massacre, a aluna escreveu um bilhete agradecendo ao policial por deter Wellington, o que ganhou grande repercussão na mídia, com direito a vídeo registrando a emoção do PM, em uma matéria do jornal Extra. E foi o depoimento ao vivo dela, com quase três minutos de duração, que comoveu a repórter do programa Estúdio I, da Globo News, caso mencionado no início deste trabalho. Ela também foi entrevistada pela apresentadora Ana Maria Braga, no Mais Você, da TV Globo, e por Wagner Montes, no Balanço Geral, da TV Record, telejornal reconhecido pelo caráter sensacionalista. A menina que toma quase todo o espaço da capa de $O$ Globo foi, portanto, exaustivamente explorada na cobertura do caso.

Mas, se por um lado, identificam-se na capa de $O$ Globo marcas textuais e apelos estéticos característicos do estilo enunciativo sensacionalista, o que a aproxima ao segundo polo da gradação, por outro, percebe-se uma preocupação do jornal em cumprir seu papel de veículo moderado. $\mathrm{O}$ enunciador procura construir uma cobertura extensa do fato. A coluna à direita da página traz o factual. A chamada "Uma carta com enigma religioso" caracteriza Wellington e aponta o fanatismo religioso como uma possível motivação para sua ação. Em "Dez meninas e 2 meninos executados", destaca-se a predileção do atirador por matar alunas - outro possível destinador-manipulador -, a ação do policial adjuvante e a punição do algoz com o suicídio de Wellington. Finalmente, na chamada "Tragédia reconduz a desarmamento", são abordadas as decisões do governo acerca do caso.

Em 2011, quando ocorreu o "Massacre de Realengo", O Globo se definia como "o jornal preferido entre os formadores de opinião", com "um público sensivelmente exigente e qualificado" e um noticiário que narrava os fatos "de maneira clara, objetiva e imparcial". O perfil dos seus leitores era composto por $62 \%$ da classe B, $19 \%$ da classe C, 
$18 \%$ da classe A e apenas $2 \%$ da classe DE (INFOGLOBO, 2011).${ }^{11}$ Esta última, considerada pelo senso comum como mais ávida a "emoções fortes", que consumiria os jornais ditos sensacionalistas, era quase insignificante diante dos demais números apresentados. Dessa forma, em uma lógica de mercado, o veículo não precisaria explorar de maneira tão exacerbada recursos de chamamento e apelo para alcançar esse público. Porém, a hiperfigurativização construída na capa sobre o episódio, com a publicação do relato de Jady e as demais estratégias descritas, evidencia que, nesse caso, $O$ Globo acabou tendendo para o polo apelativo da gradação.

\section{Considerações finais}

Em seu estudo sobre o sensacionalismo, no campo da Comunicação Social, Angrimani (cf. 1995) admite que, em alguns momentos, jornais tomados por ele como "sérios" podem se render ao estilo enunciativo sensacionalista. Porém, o autor não considera a prática comum. No âmbito dos estudos linguísticos, Discini aponta que essa prática é recorrente em ambos os perfis de veículo, ao afirmar que tanto os jornais ditos moderados quanto os reconhecidamente mais apelativos procuram sensibilizar o leitor. A diferença, de acordo com ela, é que o segundo atua nesse sentido por meio dos chamados gritos do discurso, "sem reserva e no modo da verdade [...], enquanto os outros jornais o fazem com discrição e em segredo" (DISCINI, 2003, p. 139). Com base na reflexão da autora, o desenvolvimento desta pesquisa buscou responder à seguinte pergunta: afinal, no caso da cobertura de um acontecimento apelativo por si só, como o "Massacre de Realengo" - assassinato a sangue frio, com vítimas adolescentes, tendo o ambiente escolar como cenário da violência e com o suicídio do criminoso como desfecho -, é possível estabelecer um limite preciso entre o jornal que apenas noticiou o fato e o que ampliou o apelo inerente a ele, a fim de sensibilizar os leitores?

$\mathrm{Na}$ análise das doze capas que compuseram o corpus, foram identificados em todos os veículos marcas textuais e apelos estéticos adotados de maneira a explorar a dimensão passional do caso, tais como: o destaque ao trauma causado em crianças e em adolescentes; o

$\overline{{ }^{11} \text { Disponível em: }}<$ http://goo.gl/tTg8hl $>$. Acesso em: 3 dez. 2011. 
foco no sofrimento de parentes e amigos das vítimas; o enaltecimento do policial que atirou em Wellington; a comoção compartilhada entre o jornal e o leitor; a discussão exaustiva sobre possíveis motivações para a execução do crime, envolvendo os polêmicos temas misoginia, religião e loucura; a predileção por narrar a performance do atirador; a publicação de fotos chocantes, principalmente do cadáver do algoz; depoimentos de testemunhas da ação; frames de vídeos amadores e das câmeras de segurança da escola; além da página coberta de vermelho, expressão literal do chamado jornalismo "espreme que sai sangue". Da Folha de S. Paulo a O Dia, todos os veículos analisados, de forma mais ou menos intensa, utilizaram-se de pelo menos um desses procedimentos para dramatizar ainda mais o episódio.

As particularidades da cobertura de $O$ Globo exigiram um exame mais detalhado, o que permitiu um aprofundamento na questão. Observou-se que, na capa do dia seguinte ao "Massacre de Realengo", o jornal abandonou o seu perfil inicial de enunciador "sóbrio", que procura construir principalmente simulacros de objetividade, neutralidade, imparcialidade e isenção. Ao contrário do que se esperava, recorreu a recursos de chamamento e a apelos passionais, rendendo-se preferencialmente a estratégias de manipulação que tangem ao universo sensível, aos “estados de alma” (cf. ZILBERBERG, 2006). Não se deixa de admitir que o componente afetivo é intrínseco à cobertura jornalística de mortes trágicas e/ou violentas, não apenas no discurso que tende ao sensacionalismo como também no que tende à sobriedade. $\mathrm{Na}$ análise de $O$ Globo, a questão central foi mostrar que, em um continuum traçado entre os dois polos - do menos ao mais apelativo -, o veículo se aproximou mais do segundo, configurando uma quebra de expectativa.

Dessa forma, conclui-se que pode ser errôneo estabelecer categorizações duras entre o que se define como uma linha editorial moderada e outra sensacionalista. Essa questão se apresentou de maneira bem clara a partir da análise especial dedicada a $O$ Globo, jornal com posição de protagonismo no mercado brasileiro. Com este trabalho, buscou-se colaborar para o despertar de um olhar mais crítico sobre a atuação da grande imprensa, esta que, tantas vezes, se ampara em clichês que delimitam o "bom jornalismo" como sendo o da "justa medida". Porém, em uma dimensão pragmática, evidenciou-se que a linha que separa um veículo tido como sensacionalista de um considerado moderado é mais tênue do que se imagina. Ao reconhecer essa permeabilidade, esta 
pesquisa espera contribuir para uma discussão em que as complexidades do fazer jornalístico não sejam reduzidas a discursos de cunho prescritivo ou a interesses puramente mercadológicos.

\section{Referências}

ALENCAR, A. O que é o fait divers? Considerações a partir de Roland Barthes. In: NOVA, V. C.; GLENADEL, P. (Org.). Viver com Barthes. Rio de Janeiro: 7Letras, 2005. p. 115-128.

ANGRIMANI, D. Espreme que sai sangue: um estudo do sensacionalismo na imprensa. São Paulo: Summus, 1995.

ANJ, Associação Nacional de Jornais. Maiores jornais do Brasil. Ano 2015. Disponível em: <http://goo.gl/nHMxYm>. Acesso em: 9 mai. 2016.

BARBOSA, M. A morte imaginada. In: ENCONTRO ANUAL DA COMPÓS, XIII., 2004, São Bernardo do Campo. Anais... São Bernardo do Campo: UMESP, 2004. GT Comunicação e Sociabilidade. CD-ROM.

BARROS, D. L. P. de. Teoria semiótica do texto. São Paulo: Ática, 2005.

CASTILHO, M. de S. Uma morte em família: martírio e autoridade nos 100 dias de cobertura do caso Tim Lopes em O Globo. 2005. 155 f. Dissertação (Mestrado em Comunicação e Mediação) - Universidade Federal Fluminense, Rio de Janeiro, 2005.

DISCINI, N. O estilo nos textos: história em quadrinhos, mídia, literatura. São Paulo: Contexto, 2003.

FERREIRA, A. B. de H. Novo Dicionário da Língua Portuguesa. Curitiba: Positivo, 2009.

FIORIN, J. L. Semiótica e comunicação. Galáxia - Revista Transdisciplinar de Comunicação, Semiótica, Cultura, São Paulo, n. 8, p. 13-30, 2004.

FIORIN, J. L. As astúcias da enunciação. São Paulo: Ática, 2005.

FIORIN, J. L. Elementos de análise do discurso. São Paulo: Contexto, 2011.

GOMES, R. S. Relações entre linguagens no jornal: fotografia e narrativa verbal. Niterói: EdUFF, 2008. 
INFOGLOGO. Nossos produtos. Disponível em: $<$ http://goo.gl/tTg8hl $>$. Acesso em: 3 dez. 2011.

MARTINS, E. Manual de redação e estilo de O Estado de S. Paulo. São Paulo: O Estado de S. Paulo, 1997.

NET PAPERS. O massacre de Realengo nas capas de jornais do Brasil e do mundo. Disponível em: <http://goo.gl/M3v6GL>. Acesso em: 4 jul. 2011.

SOARES, V. C. L. Manipulação pela paz na capa do jornal Meia Hora. Estudos Semióticos, São Paulo, v. 5, n. 2, p. 89-97, nov. 2009. https://doi. org/10.11606/issn.1980-4016.esse.2009.49251

VASCONCELOS, I. Tragédia no RJ: cobertura equilibrada ou sensacionalista. Comunique-se, 11 abr. 2011. $1^{\circ}$ Caderno. Disponível em: <http://goo.gl/XwMnah>. Acesso em: 13 abr. 2011.

VILAS BOAS, S. O Estilo Magazine - O texto em revista. São Paulo: Summus, 1996.

ZILBERBERG, C. Síntese da gramática tensiva. Significação - Revista Brasileira de Semiótica, São Paulo, n. 25, p. 163-204, 2006. 